
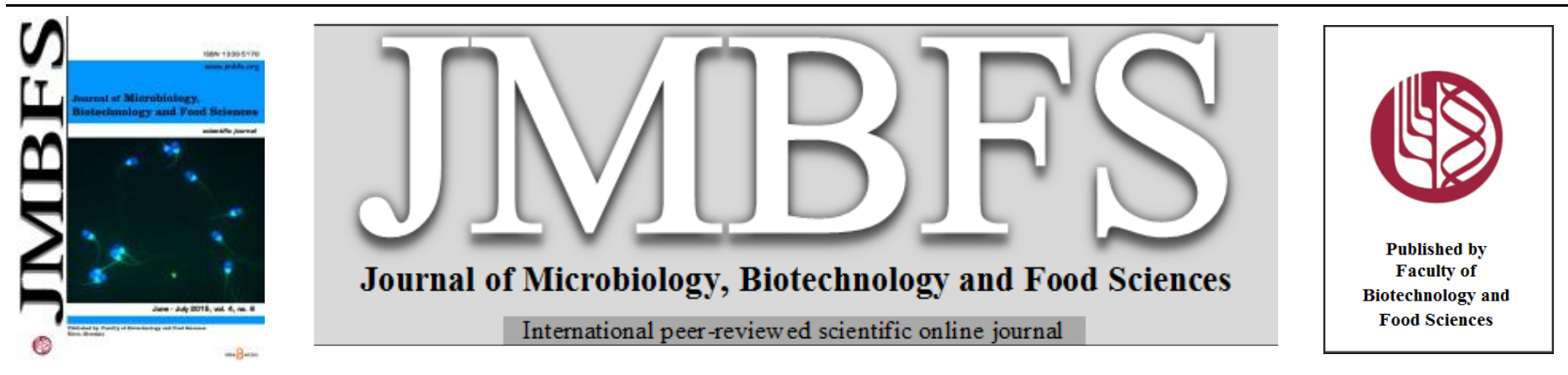

\title{
ISOLATION AND MOLECULAR CHARACTERIZATION OF EGYPTIAN TRICHODERMA AND ASSESSMENT OF THEIR ANTAGONISTIC POTENTIAL AGAINST RHIZOCTONIA SOLANI
}

\author{
Gamal Mohamedin Hassan ${ }^{*}$, Zaki Ahmed El-Feky ${ }^{1}$, Nada Fathi Hemada ${ }^{1}$,Makram Ahmeed Sayed ${ }^{2}$
}

Address(es): Gamal Mohamedin Hassan,

${ }^{1}$ Genetics department, Faculty of Agriculture, Fayoum University, 63514 Fayoum, Egypt.

${ }^{2}$ Plant protection department, Faculty of Agriculture, Fayoum University, 63514, Egypt.

*Corresponding author: gmh01@fayoum.edu.eg

doi: 10.15414/jmbfs.2015.4.6.495-502

\section{ARTICLE INFO}

Received 27. 9. 2014

Revised 23. 1. 2015

Accepted 24. 3. 2015

Published 1. 6. 2015

Regular article

OPEN $\partial_{\text {ACCESS }}$

\begin{abstract}
Morphological and molecular characterization of antagonistic ability of Trichoderma species was studied. Soil dilution plate method was used to isolate trichoderma from rhizosphere of bean, cowpea, cucumber, wheat and faba bean plants. Based on morphological and cultural characteristics, the Trichoderma isolates were identified as T. harzianum (10 isolates), T. koningii (8 isolates), and T. viride (2 isolates). A portion of rDNA, 560-600 bp was amplified from six biocontrol isolates using ITS1 and ITS 4 primers, and was sequenced and aligned against ex-type strain sequences from TrichoBlast and established Trichoderma taxonomy. Molecular phylogenetic analysis were performed based on nucleotide sequences in order to examine these isolates among 15 accession numbers of Trichoderma spp. found in GenBank. The results indicate that the FUE3, FUE5, FUE6, FUE9 and FUE18 Trichoderma isolates are closely related to Trichoderma koningii, while FUE15 isolate is closely related to Trichoderma harzianim .This result was in accordance with the result obtained from morphological and cultural characteristics. Production of volatile inhibitors and mycoparasitism were investigated using in vitro and in vivo tests in dual culture PDA medium and infected soils. The percent inhibitory effect against growth of Rhizoctonia solani was calculated, T. koningii FUE3 showed the greatest antagonistic effect to the pathogen (57.77\%) in vitro experiment whereas $T$. koningii FUE6 and FUE18 were gave the highest reduction $96 \%$ of disease incidence caused by $R$. solani in greenhouse conditions.
\end{abstract}

Keywords: Trichoderma species, Rhizoctonia solani, Ribosomal DNA, Internal transcribed spacer, Biocontrol

\section{INTRODUCTION}

The species of Trichoderma are well known and provide an effective biological control against several plant pathogens that cause major problems in the agricultural crops. The mechanisms of biocontrol including antibiosis, mycoparasitism and competition for nutrients have previously studied (Ghisalberti and Rowland, 1993; Haran et al., 1996; Simon and Sivasithamparam, 1989). Species of the genus Trichoderma are attached to the host hyphae via coiling, hooks and aspersorium- like bodies, and penetrate the host cell wall by secreting several lytic enzymes (kubicek $\boldsymbol{e t}$ al., 2001). Mycoparasites produce cell wall degrading enzymes, which allow them to bore holes into other fungi and extract nutrients for their own growth. Trichoderma are a class of imperfect fungi, without known sexual stage. They are usually found in uncultivated land sometimes in forestland and to some extent in cultivated land. It is considered as one of the efficient biocontrol agent due to its high reproductive capacity, ability to survive under very unfavorable conditions, efficiency in nutrient utilization, capacity to modify the rhizosphere, strong aggregativeness against the pathogenic fungi and efficiency in promoting plant growth and defense mechanisms (Grondona et al., 1997;Harman et al., 2004). Morphological characterization of Trichoderma species is based on microscopic measurements of mycelia fragments as well as growth rates of different isolates on different media at different temperatures, while molecular identification is based on sequence comparisons of ITS regions of rDNA gene. The morphological characters of Trichoderma have been discussed by Rifai (1969) and Bissett (1991). They emphasizing the difficulties inherent in defining morphological species of Trichoderma. Samuels (1996) also provided detailed observations and comments on the utility of morphological characters to define species in Trichoderma. The morphological characteristics need to be combined with molecular data resulting from DNA sequencing (Samuels, 2006). The internal transcribed spacer (ITS) region of the ribosomal DNA (rDNA) is one of the most reliable targets to identify a strain at the species level (KullnigGradinger et al., 2002). However, some closely related species share the sequences of their ITS regions, such as in Trichoderma sect. (Samuels, 2006). For identification of Trichoderma strains, TrichOKEY and TrichoBLAST (www.isth.info) are appropriate tools available online. Sequence data obtained from the ITS1 region of rDNA and a fragment of the translation elongation factor 1 (tef1) gene were used in a phylogenetic analysis. More than $50 \%$ of the potential biocontrol strains were grouped within Trichoderma sect. (Hermosa et al., 2004).Kindermann et al. (1998) attempted a first phylogenetic analysis of the whole genus, using sequence analysis of the ITS1 region of the rDNA. However, the use of phylogenies based on single gene sequences is now generally discredited, especially as regards the use of ITS1 and/or ITS2, as some fungi and plants have been shown to contain analogous copies (O'Donnell $\boldsymbol{e t}$ al. 1998; Lieckfeldt and Seifert, 2000). Phylogeny of Trichoderma and phylogenetic relationships of its species were investigated by maximum parsimony analysis and distance analysis of DNA sequences from multiple genetic loci. 18S rDNA sequence analysis suggests that the genus Trichoderma evolved at the same time as Hypomyces and Fusarium and thus about $110 \mathrm{Myr}$ ago. 28S rDNA sequence analysis shows that the genus Trichoderma is part of a monophyletic branch within the Hypocreaceae (Gradinger et al., 2002). The molecular analysis of several strains revealed that the classification based on morphological data has been to a great extent, erroneous resulting in reclassification of several isolates and species, (Kuhls, et al.,1996).Druzhinina and Kubicek (2005) identified Trichoderma isolates according to the physiological, phenotypic characters and molecular markers. Therefore, this study aimed to: (1) Identify Trichoderma isolates isolated from rhizosphere in this study using morphological and molecular characters. (2) Evaluate the potential of isolates as biological control against Rhizoctoni solani.

\section{MATERIAL AND METHODS}

\section{Isolation of Trichoderma isolates}

Tweenty Trichoderma isolates were isolated from rhizosphere of bean, cowpea, cucumber, wheat and faba bean plants using a soil dilution plate method described by Kucuk and Kivanc (2003). 


\section{The morphological identification of Trichoderma isolates}

Morphological identification of Trichoderma isolates was carried out according to an interactive key provided by Samuels (2002) at (http://nt.arsgrin.gov/taxadescriptions/keys/frameKey.cfm? gen=Trichoderma).Trichoderma isolates were identified to species level using the method described by Harris (2000) and confirmed by Assiut University Mycological Centre (AUMC), Assiut University,Egypt (www.aun.edu.eg/aumc/aumc.htm).

\section{Antagonistic effect against $R$. solani in vivo and in vitro}

Trichoderma isolates were evaluated for their potential to antagonize the plant pathogenic fungus $R$. solani. Bioassays were performed in vitro and in vivo according to the methods described by Anees et al. (2010) and Ahmed et al. (2000).

\section{Genomic DNA extraction from Trichoderma isolates}

Genomic DNA was extracted from the mycelium of Trichoderma isolates using the method described by Wijesinghe et al. (2010).

\section{PCR amplification of ITS region of Trichoderma isolates}

To confirm the species of strain Trichoderma at the molecular level, ITS region was amplified using universal primers ITS 1(5'-TCTGTAGGTGAACCTGCGG$\left.3^{\prime}\right)$ and ITS 4(5'-TCCTCCGCTTATTGATATGC-3')according toWhite $\boldsymbol{e t}$ al. (1990)and Gardes and Bruns (1993). Genomic DNA was amplified using a DNA thermal cycler of Applied BioSystems (USA). The reaction mixture contain $38.5 \mu \mathrm{l}$ deionized water, $5 \mu 110 \mathrm{X}$ Taq polymerase buffer, $0.5 \mu \mathrm{l}$ of $1 \mathrm{U}$ Taq polymerase enzyme, $3 \mu \mathrm{l} 2 \mathrm{mM}$ dNTPs, $1 \mu \mathrm{l}$ of $100 \mathrm{mM}$ reverse and forward primers and $1 \mu \mathrm{l}$ of $50 \mathrm{ng}$ template DNA. PCR conditions were as follows; an initial denaturation of $3 \mathrm{~min}$ at $94^{\circ} \mathrm{C}$ followed by 35 cycles of 1 min denaturation at $94{ }^{\circ} \mathrm{C}, 1 \mathrm{~min}$ primer annealing at $50{ }^{\circ} \mathrm{C}, 1 \mathrm{~min}$ extension at $72{ }^{\circ} \mathrm{C}$ and a final extension of $10 \mathrm{~min}$ at $72{ }^{\circ} \mathrm{C}$. PCR products were checked by electrophoresis using $2 \%$ agarose gel in $1 \mathrm{X}$ TAE buffer. The PCR products were then purified by using Montage PCR Clean up kit (Millipore), following manufacture instructions.

\section{Nucleotide sequencing and blast analysis}

The purified PCR products of approximately 600 bp were sequenced by automated DNA sequencing reactions, which were performed using a sequencing ready reaction kit (Life Technology) in conjunction with ABI-PRISM and ABIPRISM big dye terminator cycler. A consensus sequences were constructed by using the SeqMan ${ }^{\mathrm{TM}}$ II (windows 32 Seq Man 4.05) package (DNA star). The sequence obtained in this study was submitted to the GenBank nucleotide sequence databases accession number: KC200070, KC200071, KC200073, KC200074 and KC200075 for Trichoderma koningii FUE3, T. koningii FUE5, T. koningii FUE6, T. koningii FUE9 and T. harzianum FUE15, respectively. Sequence identities were determined using both a specific database for Trichoderma and the Genbank general database. We successively used the different tools available online from the International Subcommission on Trichoderma and Hypocrea (ISTH, www.isth.info): TrichOKEY v. 2.0 based on an oligonucleotide barcode within the ITS1 and ITS2 sequences, TrichoMARK to analyse ITS, and TrichoBLAST to detect sequence similarity in the ITS region (Druzhinina and Kubicek, 2005). In some cases, blast analysis was also performed from the National Center for Biotechnology Information (NCBI) available online. Moreover, as per requirement, the alignments of sequences were performed with the help of the program CLUSTALW 2.1 multiple sequence alignment (Larkin et al., 2007) and sequences were manually edited by visua adjustments by the help of the computer program Seaview (Galtier et al., 1996).

\section{Phylogenetic analysis}

These sequences were subjected toalignment with Trichoderma spp. sequences of the GenBank sequence database using the program BioEdit version 7.0.0 (Hall, 1999). The MEGA 4 program was used to generate a phylogenetic tree using the UPGMA method.

\section{Statistical analysis}

All data were statistically analyzed by one way analysis of variance (one way ANOVA) and post comparison was carried out with LSD test using SPSS (Statistical Package for Social Science) version 10. The results were expressed as mean \pm SD.

\section{RESULTS AND DISCUSSION}

\section{Isolation and Morphological identification of Trichoderma spp.}

A total of 20 isolates of Trichoderma spp. were isolated from rhizosphere soil of different cultivation crops (Tab 1). Culture characteristics of Trichoderma isolates including comprising growth rate, colour and colony appearance were examined and summarized in (Tab 2). These characteristics were regarded as taxonomically characteristics for Trichoderma suggested bySamuels et al. (2002). Colony appearance of the three different species grownon PDA for 5 days at $28^{\circ} \mathrm{C}$ was shown in (Fig 1). On PDAT.harzianumat the early stage whitish to greenish mycelia appeared. Next, a deep green colour developed in central part and gradually extended to the periphery, finally it appeared whitish green colour Mostly globose conidia developed on phialides produced in the opposite direction in each point (Fig1A). On PDA T. koningii was formed whitish to pale green, hairy and flappy mycelial. Next pale green turned into whitish green to dark green colour. Branched conidiophores and dendroid conidiophores terminated by phialides carried confused ellipsoids to subglobose phialospores. Phialospores were pigmented, smooth, elliposide up to a little more than $4 \mathrm{~mm}$ long (Fig 1B). In $T$. viride, colony radius on PDA in darkness after $72 \mathrm{~h}$ at $25^{\circ} \mathrm{C} 30-40 \mathrm{~mm}$, after $144 \mathrm{~h}$ in darkness conidia form abundantly in conspicuous concentric rings. Phialides typically arising singly directly from the main axis or at the tip of a short lateral branch or in whorls of 2-3 at the tips of short branches, cylindrical to somewhat swollen in the middle and sometimes with an elongated neck, straight, hooked or sinuous (Fig 1C). The Trichoderma isolates could be classified into three groups based on culture and morphological characteristics descriptions by Gams and Bissett (1998). Representative isolates from each group were sent for identification by Assiut University Mycological Centre (AUMC), Assiut University, Egypt. These species of Trichoderma were identified as 10 isolates (T. harzianum), 8 Isolates (T. koningii) and 2 isolates (T. viride) (Tab 2). $T$. harzianum was the most frequently isolated species and it was recovered in nearly all the samples. In comparison to the growth of the T. harzianum, T.koningii and T.viride form mycelia on PDA, the conidia produced by Tharzianum and T.viride somewhat resembles each other. The length of phialides of $T$. koningii was longer than rest of the two species (Tab 2). All these description were in conformity as per given by Gams and Bissett (1998).

Table 1 Isolates of Trichoderma spp. used in the present study and their origin

\begin{tabular}{|c|c|c|c|}
\hline $\begin{array}{l}\text { Isolate } \\
\text { code }\end{array}$ & $\begin{array}{l}\text { Source of } \\
\text { rhizosphere }\end{array}$ & Isolation date & Species \\
\hline FUE11 & Cucumber & June, 2004 & Trichoderma harzianum \\
\hline FUE2 & Bean & July, 2004 & Trichoderma harzianum \\
\hline FUE7 & Bean & July, 2004 & Trichoderma harzianum \\
\hline FUE14 & Cowpea & July, 2004 & Trichoderma koningii \\
\hline FUE19 & Cucumber & June, 2004 & Trichoderma viride \\
\hline FUE1 & Faba bean & $\begin{array}{l}\text { December, } \\
2004\end{array}$ & Trichoderma harzianum \\
\hline FUE5 & Faba bean & January, 2008 & Trichoderma koningii \\
\hline FUE6 & Faba bean & January, 2008 & Trichoderma koningii \\
\hline FUE17 & Faba bean & January, 2008 & Trichoderma harzianum \\
\hline FUE16 & Faba bean & January, 2008 & Trichoderma koningii \\
\hline FUE4 & Wheat & February, 2008 & Trichoderma harzianum \\
\hline FUE10 & Wheat & February, 2008 & Trichoderma harzianum \\
\hline FUE3 & Cucumber & May, 2008 & Trichoderma koningii \\
\hline FUE9 & Cucumber & May, 2008 & Trichoderma koningii \\
\hline FUE15 & Cucumber & May, 2008 & Trichoderma harzianum \\
\hline FUE8 & Bean & August, 2008 & Trichoderma harzianum \\
\hline FUE13 & Bean & August, 2008 & Trichoderma koningii \\
\hline FUE20 & Cowpea & August, 2008 & Trichoderma viride \\
\hline FUE12 & MERCEN* & - & Trichoderma harzianum \\
\hline FUE 18 & MERCEN* & - & Trichoderma koningii \\
\hline
\end{tabular}

Legend: *MERCEN,Faculty of Agriculture, Ain Shams University, Egypt. 
Table 2 Morphological characteristics of Trichoderma spp. isolated from rhizosphere

\begin{tabular}{|c|c|c|c|}
\hline $\begin{array}{l}\text { Morphological } \\
\text { characteristics }\end{array}$ & $\begin{array}{l}\text { Trichoderma } \\
\text { harzianum }\end{array}$ & $\begin{array}{l}\text { Trichoderma } \\
\text { koningii }\end{array}$ & $\begin{array}{l}\text { Trichoderma } \\
\text { viride }\end{array}$ \\
\hline $\begin{array}{l}\text { A-Conidia } \\
\text { Shape } \\
\text { Colour } \\
\text { Length } \mu \mathrm{m} \\
\text { Width } \mu \mathrm{m} \\
\text { Length/width ratio }\end{array}$ & $\begin{array}{l}\text { subglobose to } \\
\text { ovoidal } \\
\text { Dark green } \\
2.7-3.5 \\
2.4-2.9 \\
1.1-1.2\end{array}$ & $\begin{array}{l}\text { oblong to } \\
\text { narrowly } \\
\text { ellipsoidal } \\
\text { Green } \\
3.7-4.5 \\
2.8-3.2 \\
1.3-1.4\end{array}$ & $\begin{array}{l}\text { Subglobose } \\
\text { Dark green } \\
3.5-4.5 \\
3.2-3.8 \\
1.0-1.2\end{array}$ \\
\hline \multicolumn{4}{|l|}{ B-Phialides } \\
\hline Length $\mu \mathrm{m}$ & $6.5-6.7$ & $6.2-10.2$ & $7.0-11.5$ \\
\hline Midpoint $\mu \mathrm{m}$ & $2.5-3.5$ & $2.7-3.5$ & $2.5-3.5$ \\
\hline
\end{tabular}

Efficacy of antagonistic against $R$. solani in vitro

The Trichoderma species were evaluated in vitro for their potential antagonizes the plant pathogenic fungus $R$. solani. The results of antagonism between Trichoderma spp. and $R$. solani are shown in (Tab 3). Trichoderma species were showed a significant reduction in mycelia growth of fungal colonies of $R$. solan face the Trichoderma spp. compared to the control. The results showed that the best antagonistic effect against the pathogen was obtained from T. harzianum and T. koningii isolates. The Trichoderma koningii FUE3 showed the highest inhibition $(57.77 \%)$ of $R$. solani growth. On the other hand, Trichoderma viride FUE20 showed the lowest inhibition (25.33\%). The antagonism was observed with the naked eye (Fig 2). One of the mechanisms of action of Trichoderma spp. which was observed to be adapted by Trichoderma to parasites $R$. solan. $i$

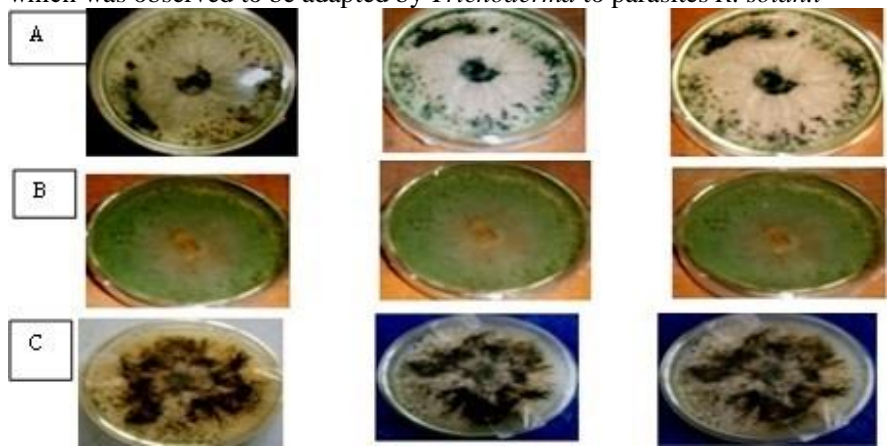

Figure 1 Colony appearance of three different species of Trichoderma grown for 5 days at $28^{\circ} \mathrm{C}$ on PDA plate.

Legend: A-T. harzianum, B- T. koningii, C-T. viride

Table 3 Antagonistic effect of Trichoderma spp. isolates against growth of phytopathogen (Rhizoctonia solani) on PDA in vitro.

\begin{tabular}{llcc} 
Isolate code & Trichoderma spp. & $\begin{array}{c}\text { Pathogen edge } \\
(\mathbf{m m}) \\
(\mathbf{M e a n} \pm \mathbf{S . ~ E )}\end{array}$ & $\begin{array}{c}\% \\
\text { inhibition }\end{array}$ \\
\hline C $($ R. solani) & Trichoderma koningii & $31.67 \pm 0.00^{\mathrm{A}}$ & 00.00 \\
FUE3 & Trichoderma harzianum & $32.50 \pm 0.1443^{\mathrm{FG}}$ & 57.77 \\
FUE15 & Trichoderma koningii & $35.00 \pm 0.0577^{\mathrm{EFG}}$ & 53.67 \\
FUE18 & Trichoderma koningii & $35.00 \pm 0.1155^{\mathrm{EFG}}$ & 53.33 \\
FUE5 & Trichoderma koningii & $35.00 \pm 0.2000^{\mathrm{EFG}}$ & 53.33 \\
FUE9 & Trichoderma koningii & $35.33 \pm 0.0882^{\mathrm{EF}}$ & 52.89 \\
FUE6 & Trichoderma koningii & $35.50 \pm 0.0289^{\mathrm{EF}}$ & 52.67 \\
FUE14 & Trichoderma harzianum & $36.00 \pm 0.0577^{\mathrm{DEF}}$ & 52.00 \\
FUE4 & Trichoderma koningii & $36.33 \pm 0.0882^{\mathrm{DE}}$ & 51.56 \\
FUE17 & Trichoderma harzianum & $36.50 \pm 0.1443^{\mathrm{DE}}$ & 51.33 \\
FUE1 & Trichoderma koningii & $36.67 \pm 0.0667^{\mathrm{DE}}$ & 51.11 \\
FUE13 & Trichoderma harzianum & $37.00 \pm 0.1155^{\mathrm{CDE}}$ & 50.67 \\
FUE8 & Trichoderma harzianum & $37.33 \pm 0.1202^{\mathrm{CDE}}$ & 50.23 \\
FUE11 & Trichoderma harzianum & $38.33 \pm 0.1764^{\mathrm{CDE}}$ & 48.89 \\
FUE2 & Trichoderma harzianum & $38.50 \pm 0.0289^{\mathrm{CDE}}$ & 48.67 \\
FUE16 & Trichoderma harzianum & $38.67 \pm 0.1333^{\mathrm{CDE}}$ & 48.44 \\
FUE10 & Trichoderma harzianum & $39.50 \pm 0.0289^{\mathrm{CD}}$ & 47.33 \\
FUE7 & & &
\end{tabular}

\begin{tabular}{llll}
\hline FUE12 & Trichoderma harzianum & $39.67 \pm 0.0333^{\mathrm{CD}}$ & 47.11 \\
FUE19 & Trichoderma viride & $40.67 \pm 0.0882^{\mathrm{C}}$ & 45.77 \\
FUE20 & Trichoderma viride & $56.00 \pm 0.2000^{\mathrm{B}}$ & 25.33 \\
\hline
\end{tabular}

Legend: * Means followed by the same letter (s) are not significantly different by LSD tes. was by competition.

Trichoderma suppressed the growth of $R$. solani through the over growth Insecond case, Trichoderma was observed to cluster around $R$. solani by the formation of small tufts thus limiting the growth of the pathogen of sheath blight In both the cases formation of sclerotial bodies of $R$. solani were suppressed (Shalini and Kotasthane, 2007). The use of specific microorganisms that interfere with plant pathogens is a nature friendly, ecological approach to overcome problems caused by the chemical method of plant protection. Research has repeatedly demonstrated that phylogenetically diverse microorganisms can act as natural antagonists of various plant pathogens (Cook, 2000). According to our results, colonies of T. harzianum and T. koningii always grew faster than $R$. solani in single or mixed culture. Rapid growth of Trichoderma is an important advantage in competition with plant pathogenic fungi for space and nutrients (Deacon and Berry, 1992).

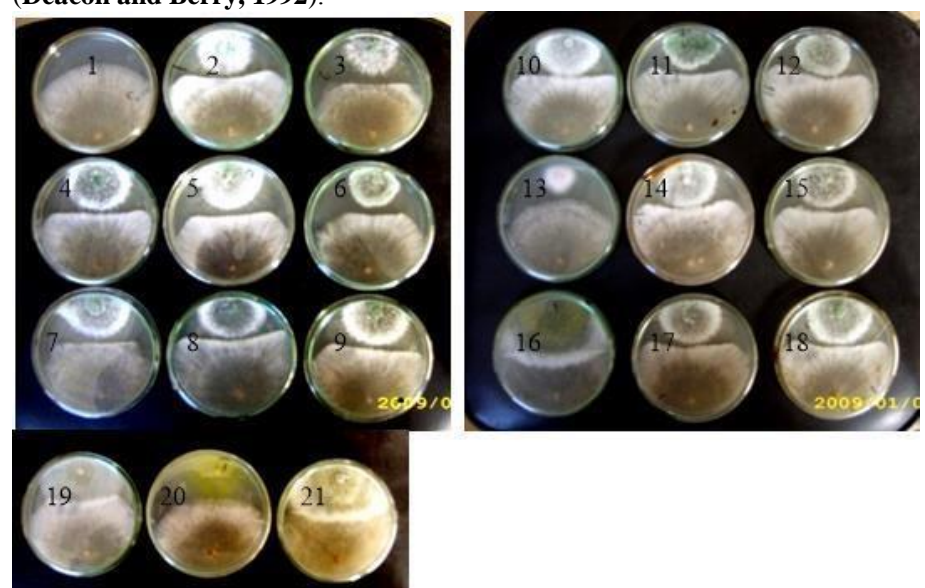

Figure 2 Antagonistic activity of Trichoderma species against $R$. solani evaluated interaction on dual culture.

Legend: 1- Control ( $R$. solani) 2-Trichoderma isolate FUEI + R. solani 3-Trichoderma isolate FUE2 + R. solani

4- Trichoderma isolate FUE3 + R. solani 6-Trichoderma isolate FUE5 + R. solani

7- Trichoderma isolate FUE6 + R. solani 9-Trichoderma isolate FUE8 $+R$. solani

10- Trichoderma isolate FUE9 + R.solani 12-Trichoderma isolate FUE11+ R. solani 13- Trichoderma isolate $I 12+R$. solani 15-Trichoderma isolate FUE14 $+R$ solani 16- Trichoderma isolate FUE15 +R.solan 18-Trichoderma isolate FUE17 + R. solani 19-Trichoderma isolate FUE18 + R.solani 21- Trichoderma isolate FUE20 + R. solani

5 -Trichoderma isolate FUE4 + R. solan

8-Trichoderma isolate FUE7 + R. solan

11-Trichoderma isolate FUE10 + R. solani 14-Trichoderma isolate FUE13 + R. solan

17-Trichoderma isolate FUE16 + R. solan 20- Trichoderma isolate FUE19 + R. solan

\section{Efficacy of antagonistic against Rhizoctonia solaniin vivo}

Selection of Trichoderma spp. for in vivo test was based on the in vitro results as explained above, such that FUE3, FUE15, FUE 18, FUE5, FUE9 and FUE6 were the best inhibition of $R$. solani. Results in (Tab 4) indicate that under greenhouse, treatments with $T$. harzianum, T.koningii significantly reduced the pre- and postemergence damping off diseases incidence under artificial infection with $R$. solani in greenhouse conditions. The damping off disease incidence caused by $R$ solani under application of Trichoderma spp. were in the range of 4-16\% and 58$74 \%$ compared to the control at pre- and post- emergence stages, respectively (Tab 4). The antagonistic effect of the six Trichoderma species against the faba bean root rot disease is shown in. (Fig 3). Results indicated that Trichoderma spp. significantly reduced the disease incidence at pre- and post- emergence stages in pot experiments. Treatments with Trichoderma spp. gave the highly protection of faba bean seedlings against damping off disease at post-emergences stage comparison with pre-emergence one. It is may be related to the ability of Trichoderma spp. to stimulate the enzymes in faba bean plants associated with increased the protection against disease. Harman et al., (2004) indicate that these fungi can induce systemic resistance in plants, thus increasing the plant defense response to diverse pathogen attack 
Table 4 Effectof Trichoderma spp. treatment on the percentage of damping-off disease of faba bean plants under greenhouse conditions (artificial inoculation)

\begin{tabular}{|c|c|c|c|}
\hline \multicolumn{4}{|c|}{ Disease assessment } \\
\hline $\begin{array}{l}\text { Damping-off \% } \\
\text { pre-emergence } \\
\text { (15 day) }\end{array}$ & $\begin{array}{l}\text { Post-emergence } \\
\text { (30 day) }\end{array}$ & Root rot (45 day) & Survival $\%$ (45 day) \\
\hline
\end{tabular}

\begin{tabular}{|c|c|c|c|c|c|}
\hline Code & Species & & & & \\
\hline $\mathrm{C}^{*}$ & Control & $0^{\mathrm{C}}$ & $0^{\mathrm{C}}$ & $0^{\mathrm{B}}$ & $100^{\mathrm{A}}$ \\
\hline $\mathrm{P}$ & R. solani & $36^{\mathrm{A}}$ & $83^{\mathrm{A}}$ & $100^{\mathrm{A}}$ & $0^{\mathrm{D}}$ \\
\hline FUE3 & T. koningii & $8^{\mathrm{BC}}$ & $74^{\mathrm{AB}}$ & $100^{\mathrm{A}}$ & $0^{\mathrm{D}}$ \\
\hline FUE5 & T. koningii & $12^{\mathrm{BC}}$ & $64^{\mathrm{B}}$ & $95^{\mathrm{A}}$ & $5^{\mathrm{C}}$ \\
\hline FUE6 & T. koningii & $4^{\mathrm{BC}}$ & $62^{\mathrm{B}}$ & $96^{\mathrm{A}}$ & $4^{\mathrm{C}}$ \\
\hline FUE9 & T. koningii & $12^{\mathrm{BC}}$ & $73^{\mathrm{AB}}$ & $100^{\mathrm{A}}$ & $0^{\mathrm{D}}$ \\
\hline
\end{tabular}

Legend: * plants grown in uninfected soil(without R.solani and/or Trichoderma)
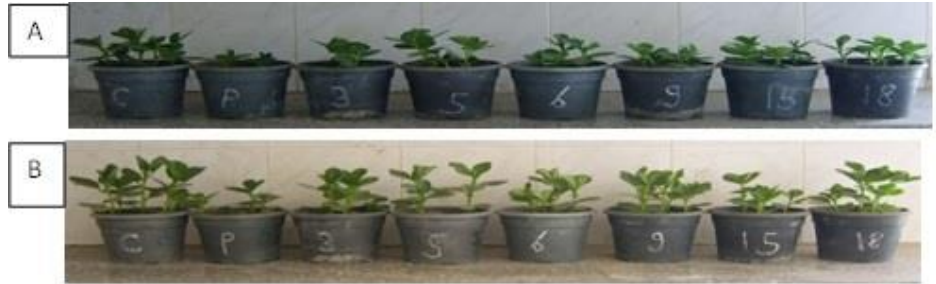

C

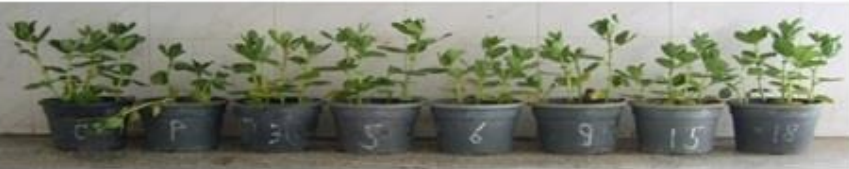

Figure 3 Effect of Trichoderma isolates on the growth of bean plants at 25, 30 and 40 days after seeding.

Legend: c- Plants grown in uninfected soil (without $R$. solani and/or Trichoderma

p- Pathogen alone, 3-FUE3+ Pathogen, 5-FUE5+ Pathogen, 6-FUE6+ Pathogen, 9-FUE9+ Pathogen, 15- FUE15+ Pathogen, 18- FUE18+ Pathogen

\section{PCR amplification of rDNA fragments}

The rDNA fragments including 5.8S gene and the flanking intergenic transcribed spacer ITS region were amplified using ITS1 and ITS4 primers. A single fragment of approximately $600 \mathrm{bp}$ nucleotide sequences was amplified from six isolates of Trichoderma (Fig 4). The results are in accordance with Mukherjee $\boldsymbol{e}$ al. (2002) who studied the identification and genetic variability of the Trichoderma isolates. These results are also in accordance with several workers who observed the amplified rDNA fragment of approximately 500 to 600 bp by ITS-PCR in Trichoderma (Ospina-Giraldo et al., 1998; Venkateswarlu et al., 2008).

\section{Identification of Trichoderma isolates}

The morphological identification of Trichoderma isolates was complemented by a molecular identification based on internal transcripted spacers (ITS region) of rDNA sequences. The few morphological characters with limited variation may lead to an overlap and misidentification of the strains and showing the necessity of DNA based characters to complete identification evident from the present study. The ribosomal DNA genes (rDNA) possess characteristics that are suitable for the identification of fungal isolates at the species level. These rDNA are highly stable and exhibit a mosaic of conserved and diverse regions within the genome (Hibbett, 1992). They also occur in multiple copies with up to 200 copies per haploid genome arranged in tandem repeats with each repeat consisting of the $18 \mathrm{~S}$ small subunit (SSU), the $5.8 \mathrm{~S}$ and the $28 \mathrm{~S}$ large subunit (LSU) genes. Internal, transcribed spacer (ITS) regions have been used to generate specific primers capable of closely related fungal species (Bryan $\boldsymbol{e t}$ al., 1995).The reliance on morphology or cultural characteristics for species determination and identification of fungi is difficult as the characteristics of isolation can change widely under varying environmental conditions (Fernando et al., 2009). In fungi genomes, ribosomal DNA (rDNA) genes include the $18 \mathrm{~S}$ $5.8 \mathrm{~S}$ and $28 \mathrm{~S}$ segment that code for ribosomal RNAs (rRNA). These are highly conserved genes that are separated by two less conserved regions, the internal transcripted spacers 1 and 2 (ITS1 and ITS2). ITS1 sequences generally vary among different species, and used widely as informative regions for PCR assays. These ITS regions have several advantages for sequencing and phylogenetic analysis of fungal species. The rate of change is appropriate for studies at the species and genus levels, the alignment for the sequences is relatively simple and results can be interpreted phylogenetically. These regions are large enough to provide potential charactersits for phylogenetic reconstruction. Further, these ITS are flanked by regions that are highly conserved within genera and species (Wijesinghe et al., 2010). Six isolates were identified at the species level by sequence analysis by ITS1 and 2 regions of the rDNA cluster. Sequence analysis of the ITS1 and 2 of rDNA has been especially reliable for the characterization of Trichoderma to the species level (Samuels et al., 2002). There is an online method for the quick molecular identification of Hypocrea/Trichoderma at the genus, clade and species levels based on an oligonucleotide barcode: a diagnostic combination of several oligonucleotides (hallmarks) specifically allocated within the ITS1 and 2 sequences of rRNA repeat (Druzhinina et al., 2005).Concerning molecular techniques, the GenBank database is generally referred, representing the largest reservoir of the sequences; however, it may not be safely used for identification as it contains many erroneous entries for Trichoderma (Druzhinina and Kubicek , 2005). This fact emphasizes the need of a specific database for Trichoderma containing only vouchered sequences, such as the ISTH (International Society on Thrombosis and Hemostasis) database has been used successfully for identification of Trichoderma strains (Zhang et al.,2005 ; Migheli et al., 2009).

Table 5 Similarity coefficient percentage among six Trichoderma isolates.

\begin{tabular}{lllllll}
\hline isolates & FUE18 & FUE9 & FUE5 & FUE6 & FUE3 & FUE15 \\
\hline FUE18 & 100 & & & & & \\
FUE9 & 98.0 & 100 & & & & \\
FUE5 & 99.0 & 99.0 & 100 & & & \\
FUE6 & 99.0 & 99.0 & 100.0 & 100 & & \\
FUE3 & 99.0 & 99.0 & 100.0 & 99.0 & 100 & \\
FUE15 & 92.0 & 93.0 & 92.0 & 92.0 & 92.0 & 100 \\
\hline
\end{tabular}

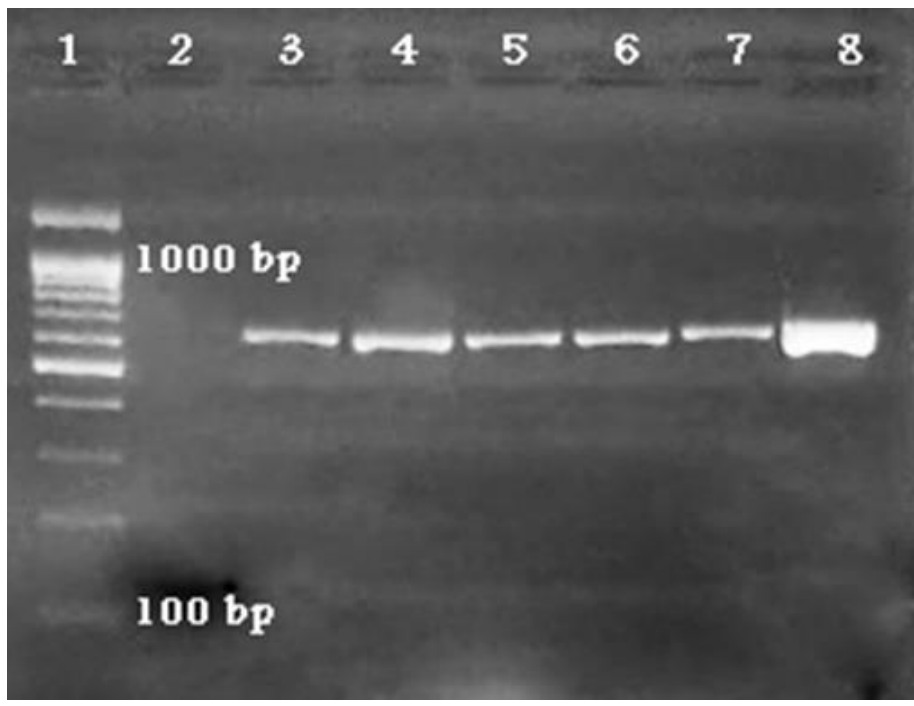

Figure 4 Agarose gel analysis of PCR products from amplification of ITS region of rDNA for Trichoderma straines.

Legend: Lane 1- 100bp DNA Ladder, Lane2- negative control, Lane3- FUE3, Lane4 FUE5, Lane5-FUE6, Lane6- FUE9, Lane7- FUE15 and Lane8- FUE18 


\section{Nucleotide sequences and Blast analysis}

Each sequence after editing was submitted to the Gene Bank and homology searches done against all the published Trichoderma sequences using BlastN and FASTA programs [National Center for Biotechnology Information (NCBI), USA]. Basic Local Alignment Search Tool (BLAST) search results of each sequence giving the closest match to the test sample was used to determine the species of Trichoderma isolates. Multiple sequence alignment was carried out including the ITS region of rDNA and gaps. There were quite a number of gaps introduced in the multiple sequence alignment within the ITS region of rDNA that were closely related, indicating a similar sequence (Fig 5). The highes homology (100\%) was found between Trichoderma species (FUE5, FUE6 and FUE3, FUE5). While the less homology (92\%) was found between isolate FUE15 and all isolates except isolate FUE9 (93\%), (Tab 5). The sequences obtained in this study was submitted to the GenBank nucleotide sequence databases (Accession numbers: KC200070, KC200071, KC200073, KC200074 and KC200075) for Trichoderma koningii FUE3, T. koningii FUE5, T. koningii FUE6, T. koningii FUE9 and T. harzianum FUE15, respectively.

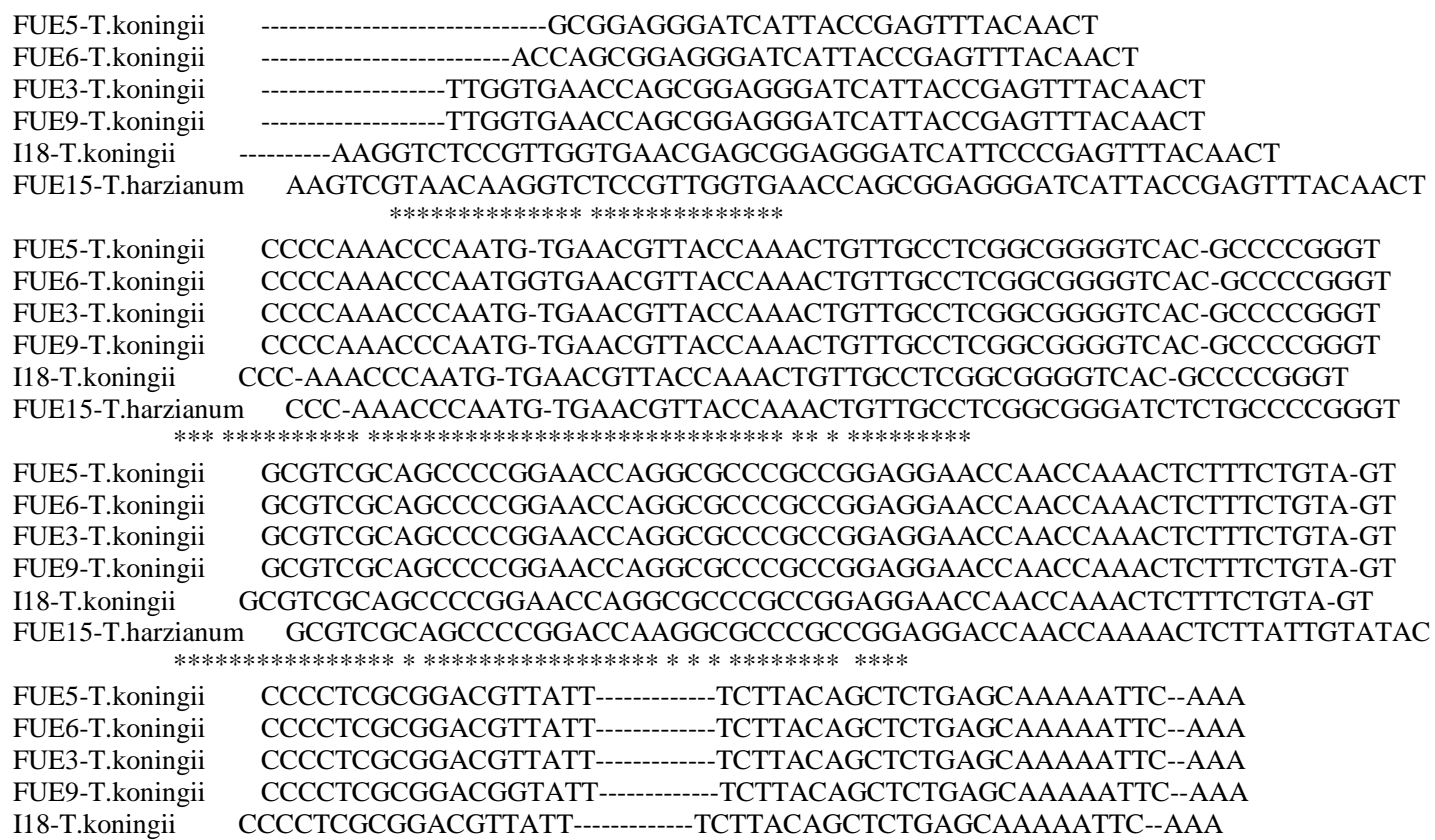

FUE5-T.koningii CAGTGGCGGTCTCGCCGCAGCCTCTCCTGCGCAGTAGTTTGCACAACTCGCACCGGGAGC FUE6-T.koningii CAGTGGCGGTCTCGCCGCAGCCTCTCCTGCGCAGTAGTTTGCACAACTCGCACCGGGAGC FUE3-T.koningii CAGTGGCGGTCTCGCCGCAGCCTCTCCTGCGCAGTAGTTTGCACAACTCGCACCGGGAGC FUE9-T.koningii CAGTGGCGGTCTCGCCGCAGCCTCTCCTGCGCAGTAGTTTGCACAACTCGCACCGGGAGC I18-T.koningii CAGTGGCGGTCTCGCCGCAGCCTCTCCTGCGCAGTAGTTTGCACAACTCGCACCGGGAGC FUE15-T.harzianum CAGTGGCGGTCTCGCCGCAGCCTCTCCTGCGCAGTAGTTTGCACA-CTCGCATCGGGAGC ****************************************************************1,

FUE5-T.koningii GCGGCGCGTCCACGTCCGTAAAACACCCAACTTTCTGAAATGTTGACCTCGGATCAGGTA FUE6-T.koningii GCGGCGCGTCCACGTCCGTAAAACACCCAACTTTCTGAAATGTTGACCTCGGATCAGGTA FUE3-T.koningii GCGGCGCGTCCACGTCCGTAAAACACCCAACTTTCTGAAATGTTGACCTCGGATCAGGTA

Figure 5 Nucleotide sequences alignment of the internal transcribed spacer (ITS region of rDNA) amplified from six Trichoderma species using CLUSTAL W 2.1 program 


\section{Phylogenetic analysis}

Based on the results obtained all the six isolates can be grouped into two main clusters. One cluster represents T. konigii (FUE15) and other T. harzianum (FUE3, FUE5, FUE6, FUE9 and FUE18), (Fig 6).The topology of UPGAM tree of the six Trichoderma isolates with 15 accession numbers of Trichoderma in the GenBank database represented a monophyletic group (Fig 7). The five Trichoderma koningii (accession numbers: KC200070, KC200071, KC200073, $\mathrm{KC} 200074$ and KC200075) were clustered with ten accession numbers of Trichoderma koningiiwithin this group, three isolates were closely related to four accession numbers of Trichoderma harzianum and formed a monophyletic lineage. Trichoderma harzianum (FUE15) was closely related to four accession numbers of Trichoderma harzianum and found a monophyletic lineage. The phylogenetic tree obtained by sequence analysis of ITS region of rDNA of six biocontrol Trichoderma strains and the sequences of fifteen other Trichoderma spp. obtained from sequence databanks is represented in (Fig 7). The ITS region of rDNA sequence was chosen for this analysis because it has been showed to be more informative with various sections of the genus Trichoderma (OspinaGiraldo et al., 1998). There are 21 Trichoderma isolates could be divided into four groups. Group 1, the T.koningii-Hypocera koningii, This group contains two subgroups one of them include Trichoderma koningii-Z79628, Trichoderma koningii-X93983, Hypocrea koningii-AJ301990, Hypocrea koningii-AY154931 and Hypocrea koningii-EU280128. The other subgroup includes the Hypocrea koningii-HQ607942, Hypocrea koningii-HQ608000, Hypocrea koningiiHQ608031 and Trichoderma koningii-AF456923 isolates. Group 2 includes two strains; include one of our biocontrol strains Trichoderma koningii FUE9 and Hypocrea koningii-AF538622. Group 3 was contained 4 of our biocontrol strains Trichoderma koningii FUE18 in the first sub subcluster. On the other hand, the second sub subclusters include Trichoderma koningii FUE5, Trichoderma koningii FUE6 and Trichoderma koningii FUE3. Group 4 includes the biocontrol strains Trichoderma harzianum FUE15, which are grouped with the representative strain Trichoderma harzianumAF194011; Trichoderma harzianumAF194009; Trichoderma harzianum AF194008; Trichoderma harzianumAF443922 in the first second sub sub group, the first sub sub group include Trichoderma harzianum AY154949 strain. The ITS PCR has helped to detect polymorphism at ITS region of rDNA among the Trichoderma isolates. Sequencing of ITS-1 and ITS-2 of the rDNA gene complex was undertaken because these regions are known to be highly variable (White et al.,1990; Bruns et al., 1991) and suitable for phylogenetic studies of fungi at the inter- and intraspecific level (O'Donnell, 1992; Egger and Sigler, 1993).

\section{CONCLUSION}

The interactive morphological key and a specific molecular database coupled with tools for identification of Trichoderma strains represent an ideal way to identify the Trichoderma spp., although, they need regular updates to include the rapidly increasing number of species of this genus.

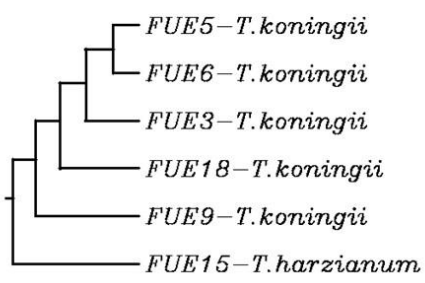

Figure 6 The Phylogenetic tree showing the relationship between the six Trichoderma strains. The rooted phylogenetic tree was constructed using the CLUSTAL W 2.1 multiple sequence alignment programs. Rooted phylogentic tree (UPGMA)

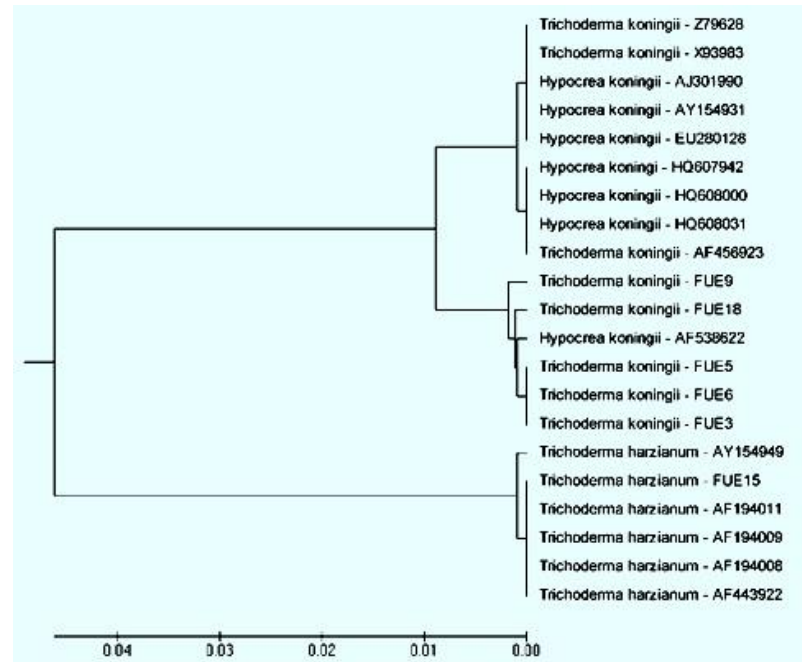

Figure 7 Phylogenetic tree showing the relationship between Trichoderma isolates. The tree was constructed using MEGA4 sequence alignment programs. Rooted phylogentic tree (UPGMA).

\section{REFERENCES}

AHMED, H.A., ABD-EL-MONEEM, K.M., ALLAM, A.D., FAHVMY,F.G. 2000. Biological control of root rots and wilt diseases of cotton. Assuit journal of Agricultural Science, 31(2), 269-286.

ANEES, M., TRONSMO, A. EDEL-HERMANN, V., HJELJORD, L.G., HERAUD, C., STEINBERG, C. 2010. Characterization of field isolates of Trichoderma antagonistic against Rhizoctonia solani. Fungal Biology .114, (9), 691-701. http://dx.doi.org/10.1016/i.funbio.2010.05.007

BISSETT, J. 1991. A revision of the genus Trichoderma.II. Infrageneric classification. Can. J. Bot. 69, 2357-2372.

http://dx.doi.org/10.1139/b91-297

BRUNS, T. D., WHITE, T. J., TALYOR, J. W. 1991. Fungal molecular systematics. Annu. Rev. Ecol. Sys. 22, 525 564.http://dx.doi.org/10.1146/annurev.es.22.110191.002521

BRYAN, G.T., DANIELS, M. J., OSBOURN, A. E. 1995. Comparison of fungi within the Gaeumannomyces and Phialophora complex by analysis of ribosomal DNA sequence. Appl. Environ. Microbiol. 61, (2), 681-689.

COOK, R. J. 2000. Advances in plant health management in the twentieth century. Ann. Rev. Phytopathol. 38, 95-116. http://dx.doi.org/10.1146/annurev.phyto.38.1.95

DEACON, J. W., BERRY, L. A. 1992. Modes of actions of mycoparasites in relation to biocontrol of soilborne plant pathogens. In: TJAMOS, E. C. PAPAVIZAS, G. C. and COOK, R. J. (eds). Biological control of plant diseases. Plenum Press, New York, 157-167.http://dx.doi.org/10.1007/978-1-4757-9468721

DRUZHININA, I., KUBICEK, C.P. 2005. Species concepts and biodiversity in Trichoderma and Hypocrea: from aggregate species to species clusters. $J$. Zhejiang Univ. Sci. 68, (2), 100-112.http://dx.doi.org/10.1631/jzus.2005.B0100 DRUZHININA, I. S., KOPCHINSKIY, A.G., KOMON, M., KUBICEK, C. P. 2005. An oligonucleotide barcode for species identification in Trichoderma and Hypocrea. Proceedings of the 8th International Mycological Congress, 21-25 August, 2006. Queensland, Australia, 1630-1700 IS2 0357.http://dx.doi.org/10.1016/j.fgb.2005.06.007

EGGER, K.N., SIGLER, L. 1993. In The Fungal Holomorph: Mitotic, Meiotic and Pleomorphic Speciation in Fungal Systematics, eds. REYNOLDS, D. R. \& TAYLOR, J. W. (CAB International, Wallingford, U.K.), 141-146.

FERNANDO, T. H., JAYASINGHE, C. K., WIJESUNDERA, R. L. SIRIWARDANA, D. 2009. Variability of Hevea isolates of Corynespora cassiicola from Sri Lanka. Journal of Plant Disease and Protection. 116, (3) 115-117.

GALTIER, N., GOUY, M., GAUTIER, C. 1996. SeaView and Phylo win: two graphic tools for sequence alignment and molecular phylogeny. Bioinformatics 12, 543-548.http://dx.doi.org/10.1093/bioinformatics/12.6.543

GAMS, W., BISSETT, J. 1998. Morphology and Identification of Trichoderma In: KUBICEK, C. P. HARMAN, G. E. (Eds.), Trichoderma and Gliocladium Basic Biology, Taxonomy and Genetics, Taylor \& Francis Ltd., London, 1, 3-34. GARDES, M., BRUNS, T. D. 1993. ITS primers with enhanced specificity for basidiomycetes - application to the identification of mycorrhizae and rusts Molecular Ecology. 2, 113-118. $\quad$ http://dx.doi.org/10.1111/j.1365294X.1993.tb00005.x

GHISALBERTI, E. L., ROWLAND, C. Y. 1993. Antifungal Metabolites FromTrichoderma harzianum. Journal of Natural Products. 56, (10), 1799 1804.http://dx.doi.org/10.1021/np50100a020 
GRADINGER, C. M., SZAKACS, G., KUBICEK, C. P. 2002. Phylogeny and evolution of the genus Trichoderma: a multigene approach. Mycol. Res. 106, (7), 757-767.http://dx.doi.org/ 10 1017/S0953756202006172

GRONDONA, I., HERMOSA, R., TEJADA, M., GOMIS, M. D., MATEOS, P. F., BRIDGE, P. D., MONTE, E., GARCIA-ACHA, I. 1997. Physiological and biochemical characterization of Trichoderma harzianum, a biological control agent against soilborne fungal plant pathogens. Appl. Environ. Microbiol. 63, (8), 3189-3198.

HALL, T. A. 1999. Bio Edit: a user-friendly biological sequence alignment editor and analysis program for Windows 95/98/NT. Nucleic Acids Symp Ser. 41, 9598.

HARAN, S., SCHICKLER, H., OPPENHEIM, A., CHET, I. 1996. Differentia expression of Trichoderma harzianum chitinases during mycoparasitism. Phytopathology. 86, 980-985.http://dx.doi.org/10.1094/Phyto-86-980

HARMAN, G. E., HOWELL, C. R., VITERBO, A., CHET, I., LORITO, M. 2004. Trichoderma species opportunistic, a virulent plant symbionts. Nature Review Microbiology. 2, (1), 43-56.http://dx.doi.org/10.1038/nrmicro797

HARRIS, J. L. 2000. Safe, low-distortion tape touch method for fungal slide mounts. Journal of Clinical Microbiology. 38, 4683-4684.

HERMOSA, M. R., KEC, E., CHAMORRA, I., RUBIO, B., SANZ, L., VIZCAINO, J. A., GRONDONA, I., MINTE, E. 2004. Genetic diversity shown in Trichoderma biocontrol isolates. Mycol. Res. 108, (8), 897906.http://dx.doi.org/10.1017/S0953756204000358

HIBBETT, D. S. 1992. Ribosomal RNA and fungal systematics. Trans. Mycol. Soc. Japan. 33, 533-556.

KINDERMANN, J., El-AYOUTI, Y., SAMUELS, G. J., KUBICEK, C. P. 1998 Phylogeny of the genus Trichoderma based on sequence analysis of the internal transcribed spacer region 1 of the rDNA cluster. Fungal Genetics and Biology. 24, 298-309.http://dx.doi.org/10.1006/fgbi.1998.1049

KUBICEK, C. P., MACH, R. L., PETERBAUER, C. K., LORITO, M. 2001 Trichoderma: From genes to biocontrol. Journal of Plant Pathology.83, (2), 1123.

KUCUK, C., KIVANC, M. 2003. Isolation of Trichoderma spp. and determination of their antifungal, biochemical and physiological features. Turkish Journal of Biology. 27, 247-253.

KUHLS, K., LIECKFELDT, E., SAMUELS, G. J., KOVACS, W., MEYER, W., PETRINI, O., GAMS, W., BORNER, T., KUBICEK, C. P. 1996. Molecular evidence that the asexual industrial fungus Trichoderma reesei is a clonal derivative of the ascomycete Hypocrea jecorina. Proc. Natn. Acad. Sci. USA. 93 7755-7760.http://dx.doi.org/10.1073/pnas.93.15.7755

KULLNIG-GRADINGER, C. M., SZAKACS, G., KUBICEK, C. P. 2002 Phylogeny and evolution of the genus Trichoderma: a multigene approach Mycological Research $\quad 106$, 767.http://dx.doi.org/10.1017/S0953756202006172

LARKIN, M. A, BLACKSHIELDS, G., BROWN, N. P., CHENNA, R., McGETTIGAN, P. A., McWILLIAM, H.; VALENTIN, F., WALLACE, I. M., WILM, A., Lopez, R. 2007. Clustal W and Clustal X version 2.0. Bioinformatics, 23: 2947.

LIECKFELDT, E., SEIFERT, K. A. 2000. An evaluation of the use of ITS sequences in the taxonomy of the Hypocreales. Studies in Mycology. 45, 35-44.

MIGHELI, Q., BALMAS, V., KOMON-ZELAZOWSKA, M., SCHERM, B., FIORI, S., KOPCHINSKIY, A. G., KUBICEK, C. P., DRUZHININA, I. S. 2009 Soils of a Mediterranean hot spot of biodiversity and endemism (Sardinia, Tyrrhenian Islands) are inhabited by pan-European, invasive species of Hypocrea/Trichoderma. Environmental Microbiology. 11, 3546.http://dx.doi.org/10.1111/j.1462-2920.2008.01736.x

MUKHERJEE, P. K., VERMA, A., LATHA, J. 2002. PCR fingerprinting of some Trichoderma isolates from two Indian type culture collection-a need for reidentification of these economically importance fungi. Science Correspondence. 83, (4), 372-374.

O'DONNELL, K. 1992. Ribosomal DNA internal transcribed spacers are highly divergent in the phytopathogenic ascomycete Fusarium sambucinum (Gibberella pulicaris). Current Genetics. 22, 213-220.http://dx.doi.org/10.1007/BF00351728 O'DONNELL, K., CIGELNIK, E., NIRENBERG, H. I. 1998. Molecular systematics and phylogeography of the Gibberella fujikuroi species complex. Mycologia. 90, 465-493.http://dx.doi.org/10.2307/3761407

OSPINA-GIRALDO, M. D., ROYSE, D. J., THON, M. R., CHEN, X., ROMAINE, C. P. 1998. Phylogenetic relationships of Trichoderma harzianum causing mushroom green mold in Europe and North America to other species of Trichoderma from world-wide sources. Mycologia. 90,7681.http://dx.doi.org/10.2307/3761014

RIFAI, M. 1969. A Revision of Genus Trichoderma. Mycological Papers, C.M.I. 116, 1-56.

SAMUELS, G. J. 1996. Trichoderma: a review of biology and systematics of the genus. Mycol. Res. 100, 923-935.http://dx.doi.org/10.1016/S09537562(96)80043-8

SAMUELS, G. J., DODD, S. L., GAMS, W., CASTLEBURY, L. A., PETRINI, O. 2002. Trichoderma species associated with the green mold epidemic of commercially grown Agaricus bisporus. Mycologia. 94, 146170.http://dx.doi.org/10.2307/3761854
SAMUELS, G. J. 2006. Trichoderma: systematics, the sexual state, and ecology. Phytopathology. 96,195-206.http://dx.doi.org/10.1094/PHYTO-96-0195

SHALINI, S., KOTASTHANE, A. S. 2007. Parasitism of Rhizoctonia solani by strains of Trichoderma spp. EJEAF.Che. 6, (8). 2272-2281.

SIMON, A., SIVASITHAMPARAM, K. 1989. Pathogen suppression: a case study in biological suppression of Gaeumannomyces graminis var. tritici in soil. Soil Biol Biochem, 21, 331-337.

WHITE, T. J., BRUNS, T., LEE, S. , TAYLOR, J. 1990. Amplification and direct sequencing of fungal ribosomal RNA genes for phylogenetics. In: INNIS, M. A., GELFAND, D. H., SNINSKY, J. J., WHITE, T. J. (eds), PCR Protocols: a guide to methods and applications Academic Press, San Diego, 315322.http://dx.doi.org/10.1016/B978-0-12-372180-8.50042-1

WIJESINGHE, C. J., WILSON WIJERATNAM, R. S., SAMARASEKARA, J. K., WIJESUNDERA, R. L. 2010. Identification of Trichoderma asperellum from selected fruit plantations of Sri Lanka. J. Natn. Sci. Foundation Sri Lanka. 38 , (2), 125-129.http://dx.doi.org/10.4038/jnsfsr.v38i2.2037

ZHANG, C. 1., DRUZHININA, I. S., KUBICEK, C. P., XU, T. 2005.

Trichoderma biodiversity in China: evidence for a North to South distribution of species in East Asia. FEMS Microbiol. Lett. 251,251257.http://dx.doi.org/10.1016/i.femsle.2005.08.034 